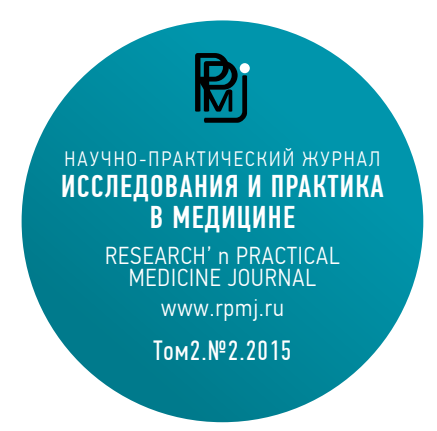

Ключевые слова:

саркома носоглотки,

рак гортани,

видеоассистированный доступ, ларингэктомия

Keywords:

sarcoma of the nasopharynx, laryngeal cancer,

video-assisted access, laryngectomy

DOI: 10.17709/2409-2231-2015-2-2-73-80

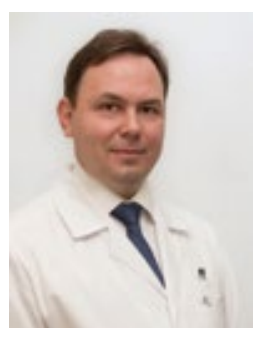

Для корреспонденции:

Поляков Андрей Павлович -

к.М.н, доцент, руководитель отделения опухолей головы и шеи МНИОИ им. П.А. Герцена филиал ФГБУ «ФМИЦ им. П.А.Герцена» Минздрава России

Адрес: 125284, Российская Федерация,

Москва, 2-й Боткинский проезд, д.3

E-mail: Appolyakov@mail.ru

Статья поступила 03.05.2015,

принята к печати 11.06.2015

For correspondence:

Polyakov Andrey Pavlovich -

$\mathrm{PhD}$, head of head and neck department

P. Hertsen MORI

Address: 2-y Botkinskiy proezd, d.3

Moskva, 125284, Russia

E-mail:Appolyakov@mail.ru

The article was received 03.05.2015

accepted for publication 11.06.2015

\section{КЛИНИЧЕСКОЕ НАБЛЮДЕНИЕ ВИДЕОАССИСТИРОВАННОГО УДАЛЕНИЯ САРКОМЫ НОСОГЛОТКИ ПОСЛЕ ОДНОМОМЕНТНОЙ ЛАРИНГЭКТОМИИ}

Поляков А.П., Волченко Н.Н., Ратушный М.В., Севрюков Ф.Е., Маторин О.В., Филюшин М.М., Васильев В.Н., Ребрикова И.В., Мухомедьярова А.А.

МНИОИ им. П.А. Герцена - филиал ФГБУ «НМИРЦ» Минздрава России

125284, Российская Федерация, г. Москва, 2-ой Боткинский проезд, дом 3

\section{Резюме:}

Саркомы в области головы и шеи достаточно редки и составляют приблизительно 5-15\% от всех сарком среди взрослых, что является менее чем 1\% от всех новообразований головы и шеи. Ввиду анатомо-физиологических особенностей строения носоглотки, хирургическое лечение опухолей этой локализации сопряжено с рядом технических трудностей, отмечен высокий риск нерадикального удаления опухоли, в связи с этим необходим адекватный хирургический доступ. В статье описан видеоассистированный доступ для удаления опухоли носоглотки с хорошей визуализацией опухолевого процесса после одномоментной ларингэктомии с формированием фарингостомы, обеспечивающей возможность наблюдения за послеоперационной областью носоглотки и раннее выявления продолженного роста опухоли у пациента с саркомой мягких тканей носоглотки и сочетанным поражением гортани.

\section{CLINICAL OBSERVATION OF VIDEO-ASSISTED REMOVAL OF SARCOMA OF THE NASOPHARYNX AFTER SIMULTANEOUS LARYNGECTOMY}

Polyakov A.P., Volchenko N.N., Ratushniy M.V., Sevrukov F.E., Matorin O.V., Filushin M.M., Vasiliev V.N., Rebrikova I.V., Mukhomedjarova A.A.

P. A. Hertsen Moscow Oncology Research Institute - branch of the National Medical Research Radiological Centre of the Ministry of Health of the Russian Federation

2-y Botkinskiy proezd, d.3, Moskva, 125284, Russia

\begin{abstract}
:
Sarcomas in the head and neck are rare, and account for approximately $5-15 \%$ of all sarcomas in adults, is less than $1 \%$ of all neoplasms of the head and neck. Due to anatomical and physiological features of the structure of the nasopharynx, surgical treatment of tumors of this localization is associated with a number of technical difficulties, the high risk of non-radical removal of the tumor, it was therefore necessary for adequate surgical access. The article describes videoassisted access for removal of tumors of the nasopharynx with good visualization of the tumor process simultaneously after laryngectomy with the formation of pharyngotomy, providing the opportunity to monitor the postoperative area of the nasopharynx and early detection of continued tumor growth in patients with soft tissue sarcoma of the nasopharynx and combined lesions of the larynx.
\end{abstract}

Саркомы мягких тканей (СМТ) представляют собой группу разнородных злокачественных опухолей, которые берут свое начало в основном из зачатков мезодермы. В настоящее время их относят к наименее изученным онкологическим заболеваниям. В общей структуре злокачественных заболеваний частота сарком мягких тканей составляет менее $1 \%$, по данным 2013 года 1,69 на 100 тыс. населения [1]. С почти равной частотой они встречаются как среди мужчин, так и среди женщин (1,85:1,60 на 100 тыс.) [1]. 
Существует большое гистологическое разнообразие вариантов сарком мягких тканей - свыше 50 гистотипов, чаще всего встречаются злокачественная фиброзная гистиоцитома и фибросаркома [2]. Зачастую саркомы мягких тканей характеризуются медленным ростом и ограниченным распространением деструкции тканей, но при этом имеют высокий потенциал отдаленного метастазирования [3]. У 9-63\% больных выявляются гематогенные метастазы, которые наиболее часто поражают легкие и кости, особенно осевого скелета; вовлечение регионарных лимфоузлов встречается гораздо реже, менее чем в 7\% случаев [4]. Также стоит отметить, что СМТ отличаются высоким риском местного рецидивирования [5]. Например, по данным Stoeckle E. с соавторами, после удаления новообразования, проведенного в качестве самостоятельного метода лечения, частота локальных рецидивов составляет от 38,8 до $81,1 \%$ [6]. При удалении саркомы мягких тканей в пределах ее псевдокапсулы рецидив опухоли встречается приблизительно у 90\% больных, при широком местном иссечении отмечается $40 \%$ частота рецидивов. [7]. Радикальное удаление опухоли (в пределах анатомической структуры) сопровождается локальными рецидивами в 10-15\% случаев. [8]. К основным прогностическим факторам при СМТ относят гистологический тип сарком, размер первичного очага (I-IV), а также наличие или отсутствие инвазивного роста [9]. Пятилетняя выживаемость составляет 50-70\%, а большинство рецидивов проявляются в течение первых 2 лет после проведенного лечения.

К факторам риска развития сарком относят различные генетические аномалии в виде синдромов и наследственных заболеваний: синдром Ли-Фраумени, нейрофиброматоз (NF1) или болезнь Реклингаузена, синдром множественного пигментного базальноклеточного рака кожи - синдром Горлинга, ретинобластома, туберозный склероз, или болезнь Бурневилла, синдром Гарднера, синдром Вернера. Также провоцирующим фактором является ионизирующее излучение, в тканях подвергшихся радиационному влиянию, риск возникновения сарком увеличивается в $10-50$ раз [10].

Саркомы в области головы и шеи достаточно редки и составляют приблизительно 5-15\% от всех сарком среди взрослых, менее чем 1\% от всех новообразований головы и шеи [11]. Область лица, шеи, волосистой части головы, носоглотки, верхнечелюстной пазухи, основание черепа и околоушная слюнная железа наиболее часто поражаются при данной локализации. Клиническое течение СМТ в области головы и шеи отличается большим разнообразием и напрямую зависит от локализации процесса; к наиболее частым симптомам относятся: головная боль, заложенность носа, дисфагия, дисфония и одышка, хотя подавляющее большинство пациентов жалоб не предъявляет [12].

Гистологически саркомы мягких тканей в области головы и шеи не отличаются от сарком других локализаций, но, из-за особенностей расположения, их хирургическое лечение сопряжено с рядом технических трудностей.

Основным методом лечения сарком мягких тканей является хирургический, однако необходим комплексный подход и участие в выработке плана лечения различных специалистов (хирургов, радиологов, химиотерапевтов), так как опухоли данной локализации часто располагаются погранично и в непосредственной близости от жизненно важных структур, что может повлиять на дальнейший план лечения. В результате, объем удаления опухоли может быть не радикальным, и таким пациентам необходимо проведение адъювантной терапии с последующим строгим динамическим наблюдением [13].

\section{Материалы и методы}

Представляем случай редкого клинического наблюдения пациента с первично-множественными синхронными опухолями: саркомой носоглотки и раком гортани.

Больной Б., 34 лет обратился в МНИОИ им. П. А. Герцена - филиал ФГБУ «НМИРЦ» МЗ РФ с жалобами на опухоль носоглотки, отсутствие дыхания через нос, снижение массы тела на 20 кг.

Из анамнеза известно, что в 08.2014 года пациент отметил появление ринорреи, затруднение носового
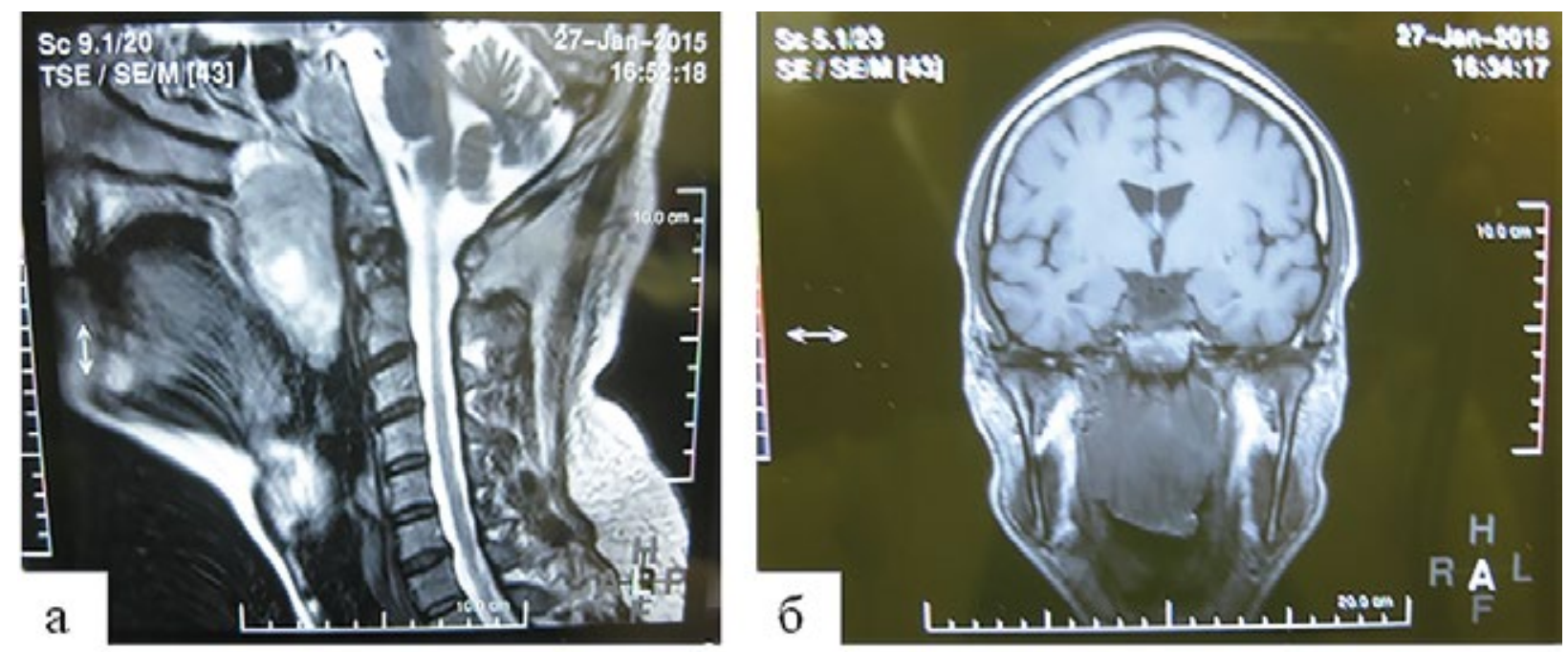

Рис. 1: МРТ лицевого отдела черепа: а) сагиттальный срез; б) фронтальный срез 
дыхания. Лечился самостоятельно, без выраженного клинического эффекта, обратился в лОР отделение по месту жительства, где 27.08.2014 года была выполнена биопсия новообразования носоглотки, при плановом морфологическом исследовании - неврилеммома. Обратился в ФГБУ НКЦО ФМБА России, где 27.10.2014 года была выполнена операция - биопсия новообразования носоглотки. При плановом морфологическом исследовании и иммуногистохимическом исследовании (ИГХ) диагностирована лейомиосаркома носоглотки. По месту жительства с 12.2014 по 01.2015 гг. проведено 2 курса полихимиотерапии по схеме: доксорубицин, ифосфамид, уромитексан. На фоне проводимого лечения выявлен продолженный рост опухоли. Пациент направлен в МНИОИ им. П.А. Герцена - филиал ФГБУ “НМИРЦ» МЗ РФ для обследования и выработки тактики лечения 12.02.2015 г.

При обращении, по данным передней и задней риноскопии просвет носоглотки обтурирован крупнобугристой опухолью, оттесняющей мягкое небо кпереди. Дыхание через нос отсутствует. При непрямой ларингоскопии в надскладочном отделе гортани слева определяется опухолевое образование, слизистая над образованием не изменена. При пальпации на шее в верхней трети справа и слева определяются увеличенные лимфатические узлы до 1,5 cм в диаметре, мягко-эластичной консистенции, подвижные, безболезненные.

По данным проведенной магнитнорезонансной томографии лицевого отдела черепа (рис. 1 а, б): в просвете носо- и ротоглотки (от свода носоглотки до уровня на 10 мм выше надгортанника) определяется образование овальной формы с четкими неровными контурами поперечными размерами до 56×32 мм протяженностью до 72 мм, накапливающее контрастный препарат, прилежащее к перегородке носа, твердому небу, оттесняя мягкое небо, компримирующее окружающие мягкотканные структуры без убедительных признаков вовлечения в процесс, за исключением правой мышцы, напрягающей небную занавеску, которая истончена. Признаков интракраниального распространения не выявлено.
В вестибулярном отделе гортани слева определяется образование округлой формы с достаточно четкими ровными контурами размерами 32×24×17 мм, деформирующее надгортанник, возможно, распространяющееся на левую черпалонадгортанную складку, которая утолщена. По данным фиброларингоскопии: у больного в проекции левой голосовой складки определяется узловое образование с ровными и четкими контурами, гипоэхогенной гетерогенной структуры, размерами 28х14 мм; носоглотка обтурирована опухолью вплоть до небной занавески. Данных за другую очаговую патологию не получено (рис. 2 а, б).

При гистологическом исследовании - злокачественное веретеноклеточное мезенхимальное новообразование с очагами некроза. Опухоль построена из полиморфных веретенообразных клеток с крупными гиперхромными ядрами, наличием митозов, в том числе патологических (от 5 до 8 в 10 репрезентативных полях зрения), участков некроза. В строме - полнокровные сосуды и кровоизлияния. При ИГХ исследовании - положительная реакция к гладкомышечному актину, отрицательная - к нейроспецифической энолазе, протеину S100. Индекс пролиферативной активности Кі 67-40\%. Лейомиосаркома носоглотки. При цитологическом исследовании пунктата из опухоли гортани - цитограмма подозрительна по принадлежности к аденокистозному раку.

Учитывая распространенность опухолевого процесса, морфологическую структуру опухоли, ее локализацию и проведенное ранее лечение, как единственный возможный в данной клинической ситуации вариант, было решено выполнить хирургическую операцию в объёме: видеоассистированное удаления саркомы носоглотки, ларингэктомию с использованием в качестве доступа к носоглотке фарингостомы, сформированной после удаления гортани.

В апреле 2015 года пациенту выполнено видеоассистированнное удаление опухоли носоглотки, ларингэктомия. Интраоперационно после мобилизации краев раны и пересечения щитовидного хряща (рис 3 а) при ревизии в области надскладочного отдела определя-
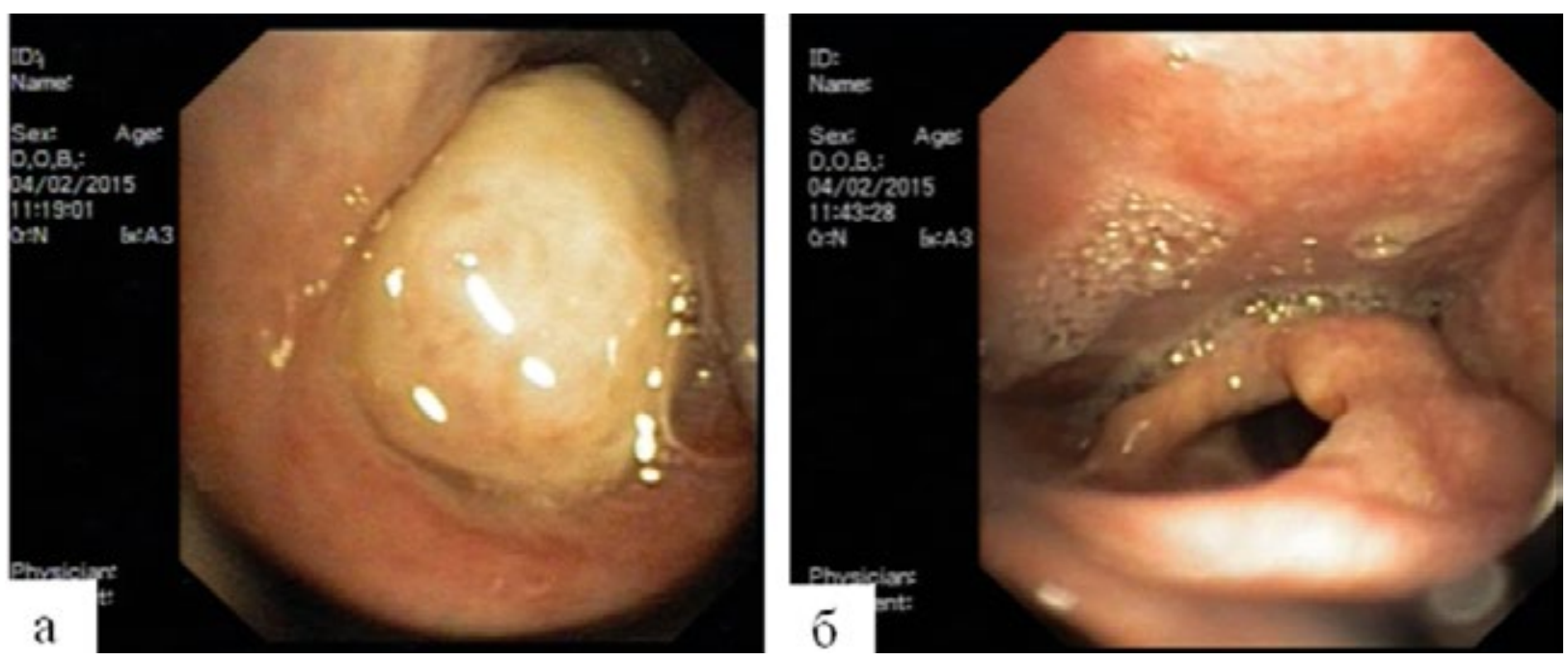

Рис. 2: а) опухоль носоглотки; б) узловое образование в проекции левой голосовой складки 
ется опухолевое образование до 3,5 cм в диаметре, на разрезе ткань саркомоподобного типа (рис. 3 б), взята биопсия. При срочном цитологическом исследовании биопсийного материала - аденокистозный рак. Учитывая локализацию, распространенность опухоли, данные двухкратного морфологического исследования, решено выполнить ларингэктомию. Выполнена надподъязычная фаринготомия. Гортань удалена в блоке с передними мышцами шеи (рис. 4 а, б).

При ревизии в носоглотке определяется крупноузловое опухолевое образование с четкими ровными контурами плотной консистенции, полностью обтурирующее полость носоглотки (рис. 5 а).

Острым и тупым путем с использованием видеоэндоскопической техники, через сформированный при ларингэктомии доступ, трансфарингеально произведена мобилизация и удаление опухоли носоглотки (рис. 5 6, 7 a).
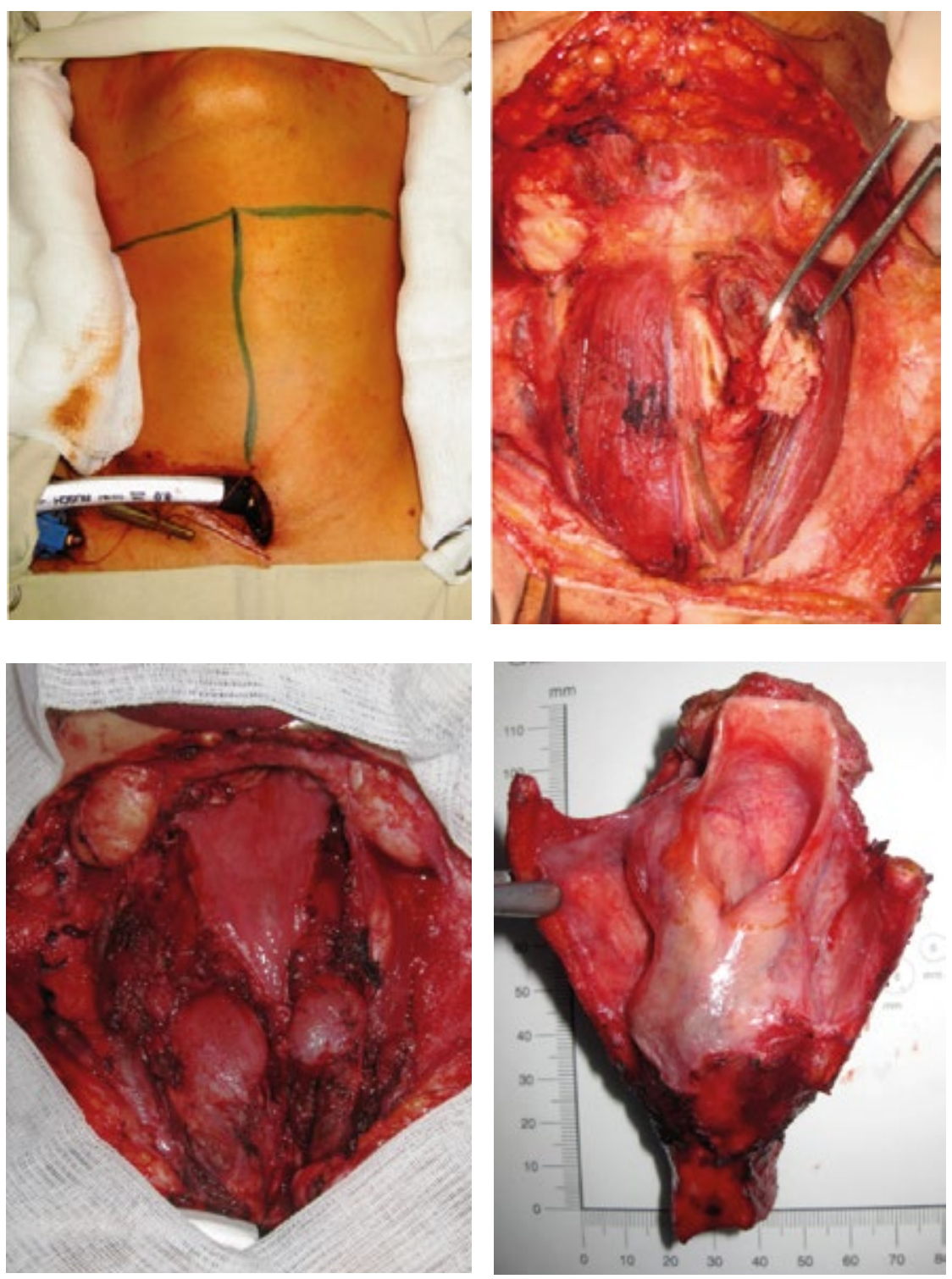

В процессе мобилизации выявлена фиксация опухоли в области правой боковой поверхности носоглотки на площади $3 \times 3$ см (рис. 6 а, б). При срочном цитологическом исследовании соскоба с тканей ложа опухоли носоглотки, после ее удаления - без опухолевого роста. Учитывая синхронность опухолевого поражения, отсутствие ответа опухоли на неоадъювантное лечение, необходимость динамического контроля и высокую вероятность рецидива, принято решение оформить фарингостому с дальнейшим решением вопроса о фарингопластике в отсроченном периоде (рис. 7 а, б).

Послеоперационный период протекал без осложнений.

При плановом морфологическом исследовании: опухоль носоглотки (рис. 8 а) представлена разрастаниями веретеноклеточной саркомы с высокой митотической активностью, без признаков лечебного патоморфоза. При ИГХ-исследовании с антителами к: СД 117 - отрицательное окрашивание клеток, СД 34 - от-

\section{Pис. 3}

а) операционный доступ;

б) биопсия опухоли гортани
Pис. 4:

а) вид раны после удаления гортани; б) удаленный препарат 
рицательное окрашивание клеток, ГМА - отрицательное окрашивание клеток, S100 - отрицательное окрашивание клеток, СД68 - отрицательное окрашивание клеток, Desm - отрицательное окрашивание клеток, Vim - положительное окрашивание клеток, Кі67-20\%. Заключение: ИГХ-картина более всего соответствует фибросаркоме. Опухоль в гортани (рис. 8 б) - аденокистозная карцинома с подрастанием к гиалиновому хрящу и многорядному цилиндрическому эпителию.

Учитывая гистологический тип саркомы носоглотки, отрицательный ответ на проведенную лекарственную терапию и объем выполненного хирургического вмешательства на консилиуме с участием хирургов, радиологов и химиотерапевтов в полеоперационном периоде было принято решение оставить больного под строгим динамическим контролем.

В результате проведенного комплексного контрольного обследования (фиброларингоскопия, МРТ, УзИ шеи, брюшной полости, рентген легких) у пациента спустя 2 месяца после операции данных за продолженный рост и метастазы не получено (рис 9).

\section{Обсуждение}

По данным отечественной и зарубежной литературы в настоящее время регистрируются лишь редкие отдельные случаи сочетанного синхронного течения саркомы носоглотки и аденокистозной карциномы гортани. Ряд исследователей предполагает, что помимо различных генетических синдромов, провоцирующих развитие сарком, наличие новообразований мягких тканей повышает риск развития вторичного опухолевого поражения (почки, молочная железа). Многоцентровые исследования показали, что у 7-10\% пациентов с СМТ развиваются вторичные опухоли в период до или после обнаружения первичного очага $[14,15,16]$. В исследовании на базе Memorial Sloan Kettering Cancer Center (Нью-Йорк) было проанализиро-
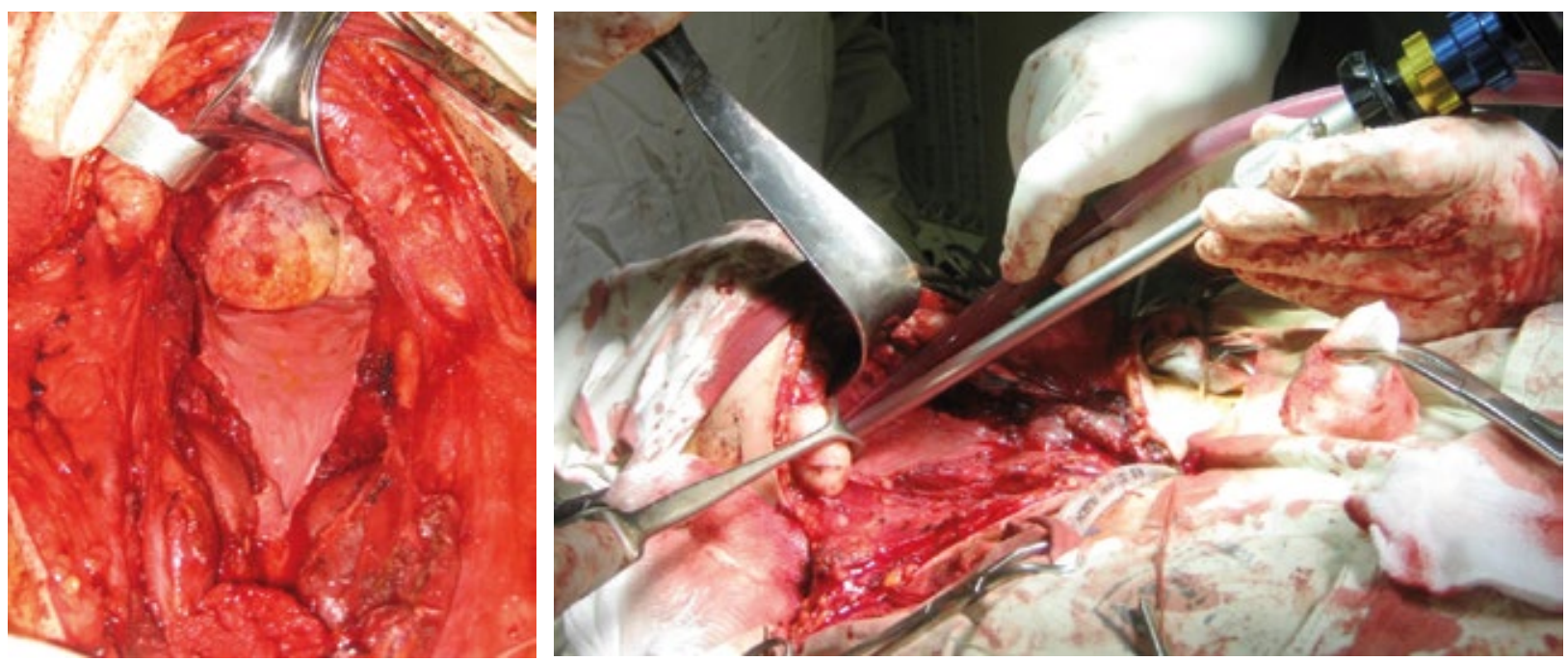

Рис. 5: а) опухоль носоглотки; б) видеоассистированное удаление опухоли носоглотки
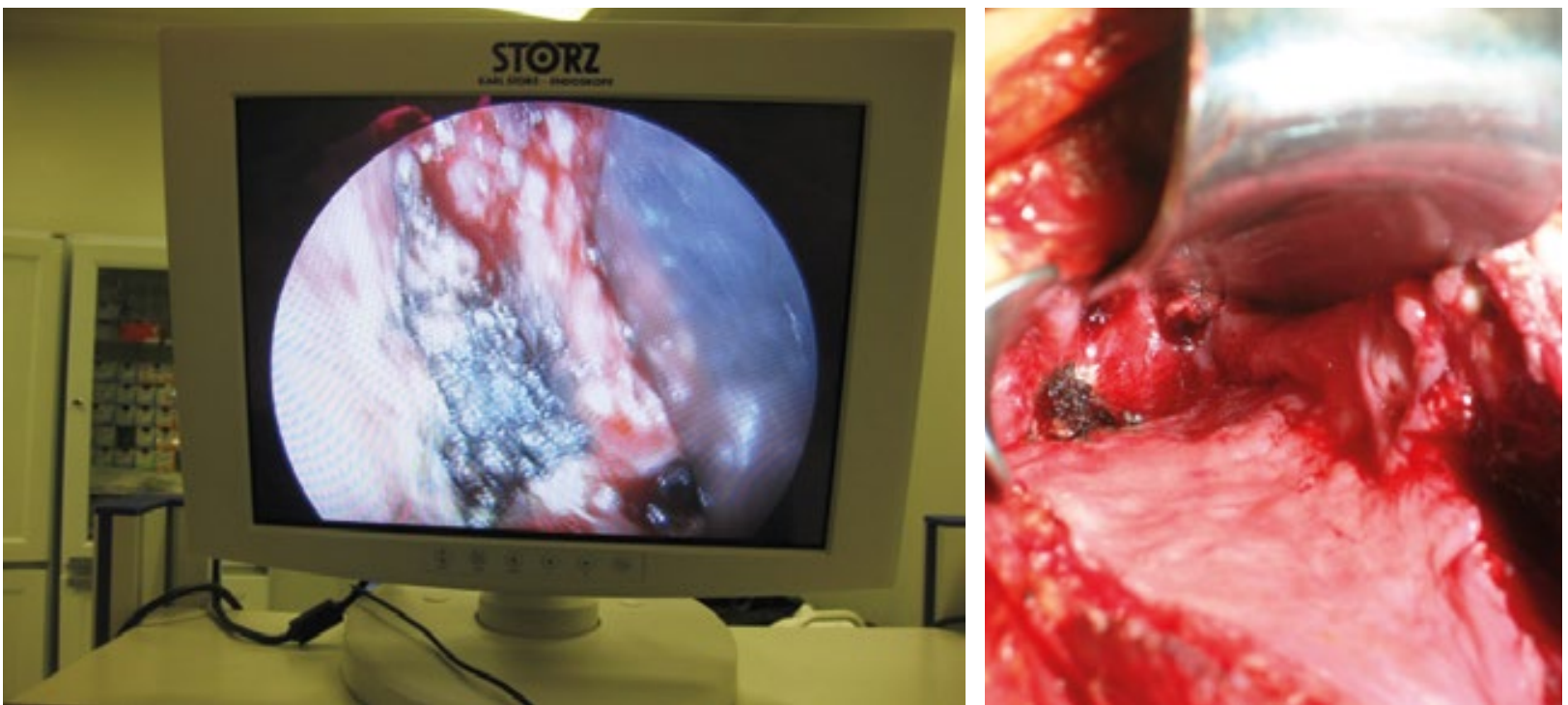

Рис. 6. а) эндофото носоглотки после удаления опухоли; б) вид ложа удаленной опухоли 
вано 5505 пациентов с клиническим диагнозом саркома мягких тканей за период с 1982 по 2003 года, только у 9 $(0,2 \%)$ пациентов наблюдалось множественное поражение, у большинства из них $(n=7)$ метахронное развитие [17]. Анализ литературных данных показал, что представленный нами клинический случай метахронного поражения саркомы носоглотки и аденокистозного рака гортани является крайне редким.

Ввиду анатомо-физиологических особенностей строения носоглотки, хирургическое лечение опухолей этой локализации сопряжено с рядом технических трудностей, отмечен высокий риск нерадикального удаления опухоли, в связи с этим необходим адекватный доступ. В настоящее время разработано порядка 20 видов хирургических доступов к носоглотке, часть из них представляет исключительно историческую ценность (например, срединное Т-образное сечение носа, отворачивание наружного носа в сторону; резекция верхней челюсти, временная резекция верхней челюсти, вскрытие снаружи лобной пазухи и решетчатого лабиринта, вскрытие гайморовой пазухи, срединный раз- рез мягкого нёба, временная резекция твердого нёба вместе с альвеолярным отростком, удаление опухоли через естественные отверстия).

В настоящее время в клинической практике наиболее часто выполняются операции с применением доступов через естественные пути, операции с применением щадящего доступа через верхнечелюстную пазуху и полость носа (операция по Денкеру), операции с применением расширенного доступа через верхнечелюстную пазуху и полость носа (операция по Муру), а также операции с применением доступа через твердое нёбо по Оуэнсу. Несмотря на такое разнообразие доступов, применяемых при патологических образованиях в полости носоглотки, существует ряд недостатков, ограничивающих их применение в тех или иных случаях. Рассечение мягкого и твердого неба для осуществления доступа к носоглотке может сопровождаться значительным кровотечением, расхождением краев мягкого неба в послеоперационном периоде и нарушением физиологической функции мягкого неба. Доступы с рассечением тканей лица, костных структур центральной

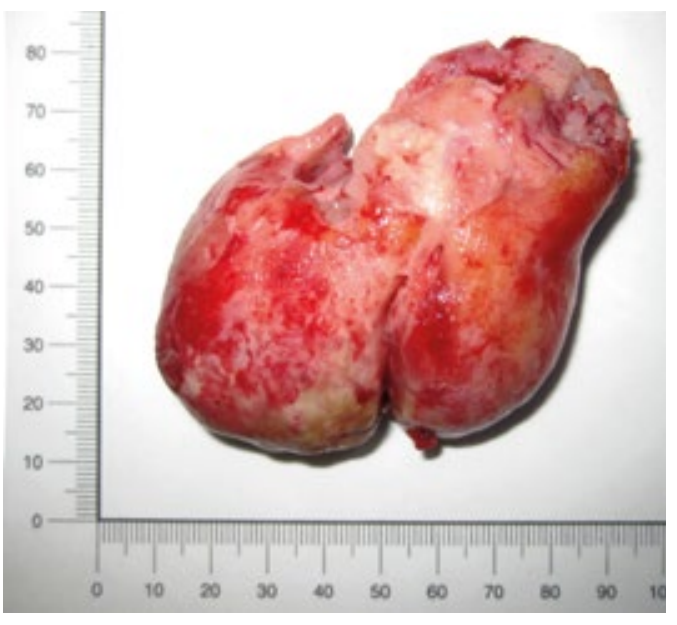

Рис. 7:

а) вид препарата (опухоль носоглотки); б) окончательный вид раны

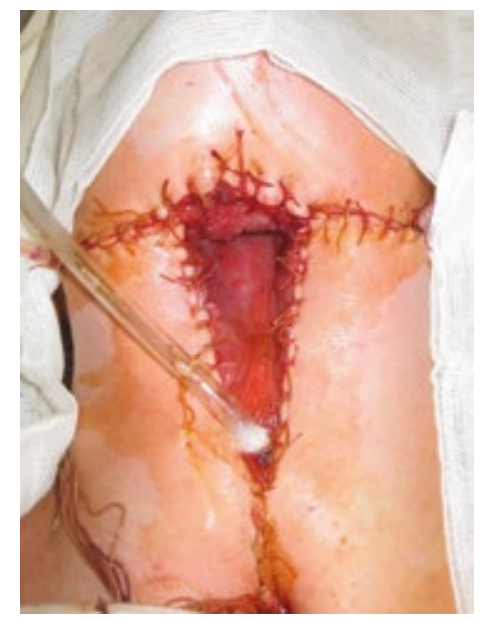

Рис. 9 Вид пациента спустя 2 месяца после операции
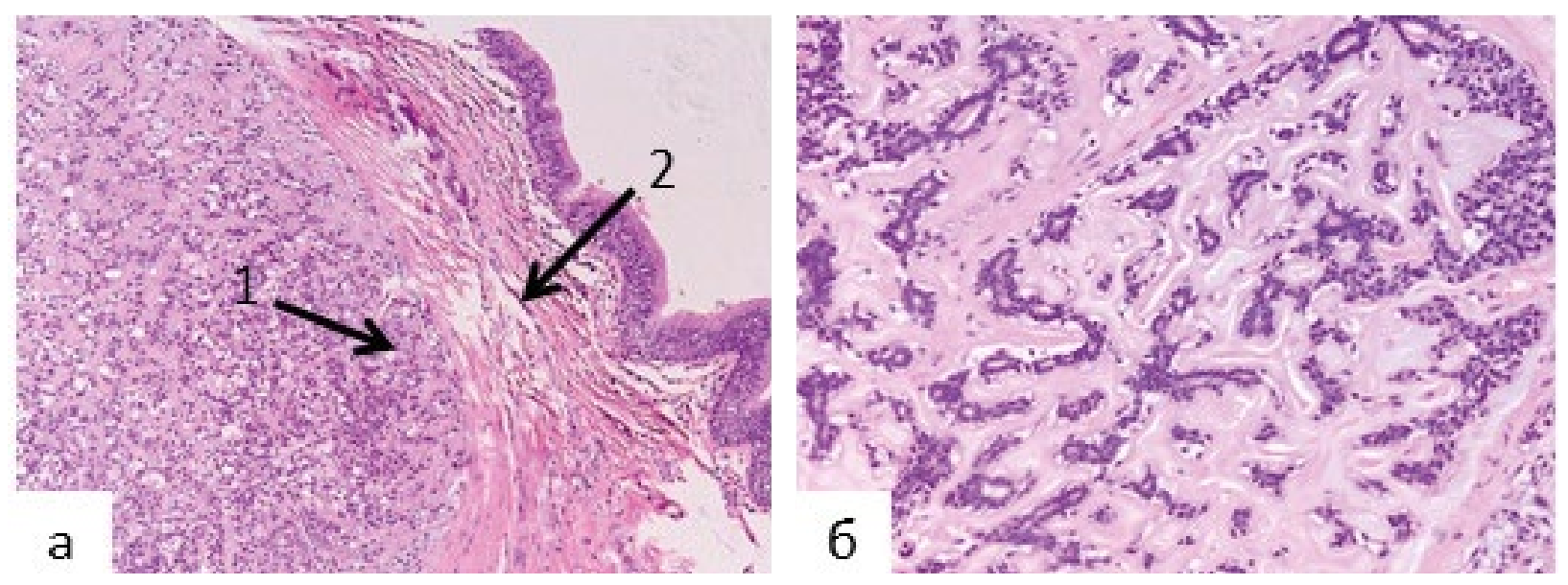

Рис. 8: а) веретеноклеточная саркома близко подрастает к хрящу, окраска гематоксилином и эозином, х100 (1 - скопление веретенообразных клеток; 2 - хрящевые клетки.); б) аденокистозная карцинома, окраска гематоксилином и эозином, х200 
зоны лица являются достаточно травматичными, с высокой вероятностью послеоперационных осложнений и косметических дефектов лица. При использовании доступов через естественные отверстия и подходом по Денкеру не создается достаточного доступа к куполу и боковым стенкам носоглотки.

\section{Заключение}

Результаты приведенного клинического наблюдения позволяют сделать вывод, что у пациента с редким гистологическим типом саркомы мягких тканей и синхронным раком гортани, выполненная ларингэктомия позволила осуществить адекватный простой доступ для удаления опухоли носоглотки без повреждения мягких тканей и костных структур центральной зоны лица с хорошей визуализацией опухолевого процесса. Сформированная при такой операции фарингостома обеспечивает возможность наблюдения за послеоперационной областью носоглотки и раннего выявления продолженного роста опухоли.
Список литературы:

1. Каприн А.Д., Старинский В.В., Петрова Г.В. Злокачественные новообразования в России в 2013 году (заболеваемость и смертность). Москва; 2015.

2. Bree de R., P. van der Valk, D.J. Kuik, et al. Prognostic factors in adult soft tissue sarcomas of the head and neck: a single-centre experience Oral Oncol, 2006; (42): 703-709.

3. Greene F.L.,Page D.L., Flemming F.D., et al (eds). American Joint Committee on cancer: cancer staging manual (6th ed.) Springer, New York. 2002; p. 221-226.

4. Fletcher C.D.M., Unni K.K., Mertens F. World Health Organization Classification of Tumours Pathology and Genetics of Tumours of Soft Tissue and Bone 2002; IARCPress Lyon, p. 100-101.

5. Barrera F.J.L., G.C.M. López, G.E. Gómez, G.A. Meneses. Sarcomas decabeza y cuello en adultos (Méx). 1997; (43): 184-188.

6. Stoeckle E., Coindre J.M., Kantor G., et al. Quality of surgery in soft tissue sarcoma: a single centre experience with the French Sarcoma Group (FSG) surgical system. Cancer Ther. 2005; (3): 31-39.

7. Hoshi M., leguchi M., Takami M., et al. Clinical problems after initial unplanned resection of sarcoma. Jpn J ClinOncol. 2008; 38(10): 701-709.

8. LeVay J., O'Sullivan B., Catton C., et al. Outcome and prognostic factors in soft tissue sarcoma in the adult. Int. J. Radiat. Onco. Biol. Phys.1993; (27): 1091-1099.

9. Scott S.M, Reiman H.M, Pritchard D.J, Ilstrup D.M. Soft tissue fibrosarcoma. A clinicopathologic study of 132 cases. Cancer. 1989; (64): 925-931.

10. Berrington de Gonzalez A., Kutsenko A., Rajaraman P. Sarcoma risk after radiation exposure. Clin Sarcoma Res. 2012; 2(1): 18

11. Patel S.G., Shaha A.R.,Shah J.P. Soft tissue sarcomas of the head and neck: an update. Am J Otolaryngol. 2001; (22): 2-18

12. Colville R.J.,Charlton F., Kelly C.G., et al. Multidisciplinary management of head and neck sarcomas. Head Neck. 2005; (27): 814-824

13. Le Q.T., Fu K.K., Kroll S., et al. Prognostic factors in adult soft tissue sarcomas of the head and neck. Int J Radiat Oncol Biol Phys. 1997; (37): 975-984

14. Tateishi U., Hasegawa T., Yamamoto S., et al. Incidence of multiple primary malignancies in a cohort of adult patients with soft tissue sarcoma. Jpn J ClinOncol. 2005; (35): 444-452.

15. Merimsky O., Kollender Y., Issakov J., et al. Multiple primary malignancies in association with soft tissue sarcomas. Cancer.2001; (91): 1363-1371.

16. Thijssens K.M., van Ginkel R.J., Suurmeijer A.J., et al. Radiationinduced sarcoma: a challenge for the surgeon. Ann Surg Oncol. 2005; (12): 237-245.

17. Grobmyer S.R., Luther N., Antonescu C.R., et al. Multiple primary soft tissue sarcomas. Cancer. 2004;101(11):2633-2635.
References:

1. Kaprin A.D., Starinskii V.V., Petrova G.V. Zlokachestvennye novoobrazovaniya v Rossii v 2013 godu (zabolevaemost' i smertnost'). Moskva; 2015.

2. Bree de R., P. van der Valk, D.J. Kuik, et al. Prognostic factors in adult soft tissue sarcomas of the head and neck: a single-centre experience Oral Oncol, 2006; (42): 703-709.

3. Greene F.L.,Page D.L., Flemming F.D., et al (eds). American Joint Committee on cancer: cancer staging manual (6th ed.) Springer, New York. 2002; p. 221-226.

4. Fletcher C.D.M., Unni K.K., Mertens F. World Health Organization Classification of Tumours Pathology and Genetics of Tumours of Soft Tissue and Bone 2002; IARCPress Lyon, p. 100-101.

5. Barrera F.J.L., G.C.M. López, G.E. Gómez, G.A. Meneses. Sarcomas decabeza y cuello en adultos (Méx). 1997; (43): 184-188.

6. Stoeckle E., Coindre J.M., Kantor G., et al. Quality of surgery in soft tissue sarcoma: a single centre experience with the French Sarcoma Group (FSG) surgical system. Cancer Ther. 2005; (3): 31-39.

7. Hoshi M., leguchi M., Takami M., et al. Clinical problems after initial unplanned resection of sarcoma. Jpn J ClinOncol. 2008; 38(10): 701-709.

8. LeVay J., O'Sullivan B., Catton C., et al. Outcome and prognostic factors in soft tissue sarcoma in the adult. Int. J. Radiat. Onco. Biol. Phys.1993; (27): 1091-1099.

9. Scott S.M, Reiman H.M, Pritchard D.J, Ilstrup D.M. Soft tissue fibrosarcoma. A clinicopathologic study of 132 cases. Cancer. 1989; (64): 925-931.

10. Berrington de Gonzalez A., Kutsenko A., Rajaraman P. Sarcoma risk after radiation exposure. Clin Sarcoma Res. 2012; 2(1): 18.

11. Patel S.G., Shaha A.R.,Shah J.P. Soft tissue sarcomas of the head and neck: an update. Am J Otolaryngol. 2001; (22): 2-18

12. Colville R.J.,Charlton F., Kelly C.G., et al. Multidisciplinary management of head and neck sarcomas. Head Neck. 2005; (27): 814-824.

13. Le Q.T., Fu K.K., Kroll S., et al. Prognostic factors in adult soft tissue sarcomas of the head and neck. Int J Radiat Oncol Biol Phys. 1997; (37): 975-984

14. Tateishi U., Hasegawa T., Yamamoto S., et al. Incidence of multiple primary malignancies in a cohort of adult patients with soft tissue sarcoma. Jpn J ClinOncol. 2005; (35): 444-452.

15. Merimsky O., Kollender Y., Issakov J., et al. Multiple primary malignancies in association with soft tissue sarcomas. Cancer.2001; (91): 1363-1371.

16. Thijssens K.M., van Ginkel R.J., Suurmeijer A.J., et al. Radiationinduced sarcoma: a challenge for the surgeon. Ann Surg Oncol. 2005; (12): 237-245.

17. Grobmyer S.R., Luther N., Antonescu C.R., et al. Multiple primary soft tissue sarcomas. Cancer. 2004;101(11):2633-2635. 
Информация об авторах:

1. Поляков Андрей Павлович - к.м.н, доцент, руководитель отделения опухолей головы и шеи МНИОИ им. П.А. Герцена - филиал ФГБУ «ФМИЦ им. П.А.Герцена» Минздрава России

2. Волченко Надежда Николаевна - д.м.н., профессор, руководитель патологоанатомического отделения МНИОИ им. П.А. Герцена - филиал ФГБУ «ФМИЦ им. П.А.Герцена» Минздрава России

3. Ратушный Михаил Владимирович - к.м.н., с.н.с. отделения микрохирургии МНИОИ им. П.А. Герцена - филиал ФГБУ «ФМИЦ им. П.А.Герцена» Минздрава России

4. Севрюков Феликс Евгеньевич - к.м.н., заведующий отд. микрохирургии МНИОИ им. П.А. Герцена - филиал ФГБУ «ФМИЦ им. П.А.Герцена» Минздрава России

5. Маторин Олег Владимирович - к.м.н., с.н.с. отделения микрохирургии МНИОИ им. П.А. Герцена - филиал ФГБУ «ФМИЦ им. П.А.Герцена» Минздрава России

6. Филюшин Михаил Михайлович - к.м.н., врач - онколог отделения микрохирургии МНИОИ им. П.А. Герцена - филиал ФГБУ «ФМИЦ им. П.А.Герцена» Минздрава России

7. Васильев Валентин Николаевич - к.м.н., научный сотрудник отделения микрохирургии МНИОИ им. П.А. Герцена - филиал ФГБУ «ФМИЦ им. П.А.Герцена» Минздрава России

8. Ребрикова Ирина Валерьевна - младший научный сотрудник отделения микрохирургии МНИОИ им. П.А. Герцена филиал ФГБУ «ФМИЦ им. П.А.Герцена» Минздрава России

9. Мухомедьярова Альбина Анатольевна - врач-ординатор отделения микрохирургии МНИОИ им. П.А. Герцена - филиал ФГБУ «ФМИЦ им. П.А.Герцена» Минздрава России
Information about authors:

1. Polyakov Andrey Pavlovich - PhD, head of head and neck department P. Hertsen MORI

2. Volchenko Nadezhda Nikolaevna - MD, head of pathology department P. Hertsen MORI

3. Ratushniy Mikhail Vladimitovich - PhD, senior researcher of head of head and neck department P. Hertsen MORI

4. Matorin Oleg Vladimitovich. - PhD, senior researcher of head of head and neck department P. Hertsen MORI

5. Sevrukov Felix Evgenyevich - PhD, chief of head and neck department P. Hertsen MORI

6. Filushin Mikhail Mikhailovich - PhD, P. Hertsen MORI

7. Vasiliev Valentin Nikolaevich- PhD, P. Hertsen MORI

8. Rebrikova Irina Valerievna - PhD, P. Hertsen MORI

9. Mukhomedjarova Albina Anatolyevna - resident of head of head and neck department P. Hertsen MORI

\section{Оформление ссылки для цитирования статьи:}

Каприн А.Д., Поляков А. П., Волченко Н.Н., Ратушный М. В., Севрюков Ф. Е., Маторин О. В., Филюшин М. М., Васильев В. Н., Ребрикова И.В., Мухомедьярова А.А. Клиническое наблюдение видеоассистированного удаления саркомы носоглотки после одномоментной ларингэктомии. Исследования и практика в медицине. 2015; 2 (2): 73-80. DOI: 10.17709/2409-2231-2015-2-2-73-80

Kaprin A.D., Polyakov A.P., Volchenko N.N., Ratushniy M.V., Sevrukov F.E., Matorin O.V., Filushin M.M., Vasiliev V.N., Rebrikova I.V., Mukhomedjarova A.A. Clinical observation of video-assisted removal of sarcoma of the nasopharynx after simultaneous laryngectomy. Issled. prakt. med. 2015; 2(2): 73-80. DOI: 10.17709/2409-2231-2015-2-2-73-80

Конфликт интересов. Все авторы сообщают об отсутствии конфликта интересов. Conflict of interest. All authors report no conflict of interest. 